\title{
Darwinism, Mind and Society
}

\author{
LOUIS CARUANA
}

It is one of the ironies of history that Charles Darwin wasn't the real founder of Social Darwinism. If one were pressed to pick out a single founder, it must be Herbert Spencer. This fact alone is enough to indicate the complex nature of the interaction between Darwin's empirical work and its application to human social and moral behavior. Some years before the publication of Darwin's Origin of Species, Herbert Spencer, had argued that Nature deals with the healthy by letting them survive and with the weak by letting them die. We should therefore do likewise in human society: "If they are sufficiently complete to live, they do live, and it is well they should live; if they are not sufficiently complete to live, they die, and it is well they should die."1 Such an attitude towards nature and society was quite widespread before Darwin. The basic features of this attitude included the belief that Nature produced inequalities. As a consequence, social phenomena must be explained in terms of competition, conflict and the equilibrium and adjustment that results from this.

Darwin's specific contribution came from his two core principles: first, that all species are descended from one progenitor; and second, that the mechanism how this descent occurs is natural selection. Biologists today may leave it as an open question whether one should assume just one progenitor or perhaps a very small number, and whether or not natural selection is the only mechanism involved. Nevertheless, we can say that Darwin's two core principles, which determine a unique research program in 
the history of science, have withstood more than a hundred years of scrutiny. Is it possible to separate the scientific core of his theory from extrapolations of it to moral and social theory? Is it possible to separate the scientist Darwin from the ideological Darwin? Anyone who wants to answer in the affirmative would have to start with Darwin himself. Darwin himself saw his own work as extendable, without losing its continuity, from empirical observation of animal characteristics to questions related to morals and religion. As Spencer and others had done before him, Darwin considered it an essential part of his intellectual task to extrapolate his core principles to areas beyond the horizon of strictly empirical study. He worked out theories of the evolution of cognitive dispositions or habits, of ethics, and even of religious behavior. For instance, in his 1871 work The Descent of Man, and Selection in Relation to Sex, he asked: are high moral standards advantageous? As regards the community, he answered in the affirmative. He observed that a tribe with self-sacrificing individuals would have survival advantage over another tribe without such individuals. In the long run, this results in natural selection. And hence, what he called "standards of morality" tend to rise, in the sense that tribes with individuals open to the possibility of self-sacrifice tend to outlive other kinds of tribes. ${ }^{2}$ Since then, many other thinkers took up Darwin's project of extrapolating evolutionary explanation so as to engage with philosophy of mind, ethics, and social and political philosophy. Not all of them agree on the extent to which such an extrapolation is legitimate. At one extreme we find some who insist that philosophy and natural science don't mix, and should therefore be kept apart. For these, natural selection in the evolution of hominids is completely irrelevant for the resolution of problems in these areas. At the other extreme, we find other thinkers insisting that philosophical problems we have been 
facing since time immemorial have been, and are being, resolved steadily as natural science pushes ahead.

The area represented by the middle ground between these two extremes is not easy to navigate. The issues as they stand today are multifaceted and compound, branching out into various areas of philosophy and theology. It is one of the aims of this chapter to add some clarity into this complex area of inquiry. I intend to do this with special attention to two traditions: the secular and the religious. In part one, I will concentrate on purely philosophical issues, tracing the development of the idea of social Darwinism, from its origins to the present day. At the end of this first part, I will be in a position to determine one major root problem that is blocking further progress in the current state of things. In part two, I will shift into the religious mode of inquiry. I will give a sketch of the main features of the reaction to social Darwinism that arose from Catholic scholarship. I will then proceed by determining, from within this Catholic tradition, the main root problem of social Darwinism as perceived from the religious viewpoint. These two lines of inquiry will enable us then to appreciate the extent to which the root problems determinable from secular, philosophical inquiry correspond to the root problems determinable from the Catholic tradition. $^{3}$

\section{SOCIAL DARWINISM: THE PHILOSOPHICAL PERSPECTIVE}

Darwin's attempts at explaining moral and social behavior illustrate a social theory in the making, itself situated within a wider paradigm. This wider world-view had various characteristics. It included, for instance, an overall slant towards materialist explanation of human psychological and social affairs. It included also, as 
a consequence, a suspicion as regards any supernatural forces. The view that human beings were somehow evolved from non-human organisms was already present before Darwin. Moreover, even before Darwin's time, the search had been on for biological laws that would explain the entire range of living organisms. Many authors had discussed the fact that population growth affects the way living things compete for resources. The historian Mike Hawkins describes this paradigm by mentioning four features:

This world view [...] consisted of the following elements: (i) biological laws governed the whole of organic nature, including humans; (ii) the pressure of population growth on resources generated a struggle for existence among organisms; (iii) physical and mental traits conferring an advantage on their possessors in the struggle (or in sexual competition), could, through inheritance, spread through the population; (iv) the cumulative effects of selection and inheritance over time accounted for the emergence of new species and the elimination of others. ${ }^{4}$

What Darwin added to this paradigm was a robust empirical basis. After the publication of the Origin of Species, supernatural and teleological accounts of species formation lost much of their previous plausibility. The urge to extend the naturalselection mode of explanation beyond the physical properties of humans became stronger and stronger. Social Darwinism, from that period onwards, can therefore be described as follows. It is the research program in which what Darwin did for physical and biological features is assumed extendible to human social existence and also to human psychological attributes that determine the modalities of this social existence, especially morality and religion. ${ }^{5}$ 
This program, of course, didn't proceed without its share of opposition. To obtain some idea of the various kinds of challenges it had to face, the first thing one needs to keep in mind is that Social Darwinism was "a broad church". ${ }^{6}$ On the one hand we have people like Thomas Robert Malthus who had prepared the background by highlighting the mutual dependence between population growth and conditions for survival. He argued that the less deprived will face more demanding conditions, because population grows at a geometric rate while food resources can only grow at an arithmetic rate. This preliminary trace of Social Darwinism can therefore be seen as that paradigm's pessimistic trend. On the other hand, we find Herbert Spencer, who was transforming biological thinking, albeit in its Lamarckian form, into a robust social philosophy with implications for economics, this time in an optimistic way. $\mathrm{He}$ emphasized a laissez-faire attitude that, according to him, guarantees progress. Both flanks had to face opposition. Malthusian thinking had to respond to the objection that an increase in population doesn't only mean an increase in need for resources but also an increase in productivity. Spencer's writings had to respond to objections related to the foundations of ethics. G.E. Moore argued in his Principia Ethica that Spencer had committed the naturalistic fallacy. According to Moore, Spencer errs because he allegedly substituted a non-natural property, namely goodness in itself, by a natural property, namely survivability. ${ }^{7}$ The wider ramifications of this "broad church" gave rise to controversies that had international significance and survived all through the twentieth century. Social Darwinism was linked to the eugenic movements in the USA and in Nazi Germany, and was also implicated within the nature-nurture debate in the development of human anthropology. On the one hand, anthropological studies in the first decades of the twentieth century, for instance those carried out by Margaret Mead, suggested that most human action is a result of environmental conditioning and 
not of genetic constitution. These studies therefore tended to undermine Social Darwinism. On the other hand, more recent studies in molecular genetics, like those of W.D. Hamilton in 1964, and E.O. Wilson in 1975, started supplying empirical evidence on how a specific genetic constitution indeed determines, to some extent at least, what humans do. ${ }^{8}$

The unifying characteristic of all the variations of Social Darwinism seems to lie in their common assumption. They all assume that humans, like other animals, compete for existence and that this fundamental feature explains the most useful aspects of social and political reality. If this assumption is made stronger, a more radical position results. If, in other words, we assume that the competition for existence explains not just most aspects of social and political reality but all of that reality, we end up with sociobiology. This position involves the idea of reduction. It works with the assumption that disciplines that have been up to now considered nonempirical, like ethics, psychology, social and political theory, are indeed entirely empirical after all. They are branches of biology. Sociobiology therefore can be considered an extreme version of Social Darwinism: a naturalistic Social Darwinism. ${ }^{9}$ Of course, naturalism is most often described with respect to physics: physics is taken to be the core, or the only, discipline that matters in all philosophical topics. Here we have naturalism with respect to biology. Society is assumed totally explainable just like flora or fauna. There are various levels of organization, and each is explainable in terms of evolution propagated by blind variation and natural selection alone. Moreover, human society, just like the rest of the organic world, is explainable in terms of purposes, goals, and functions of systems situated within larger systems. ${ }^{10}$

With these general features of Social Darwinism in view, we can now appreciate some typical arguments in its favor in current literature. A good source is 
Michael Ruse's Taking Darwin Seriously. In this book, he takes the most convincing justification for sociobiology to be the success with which altruistic behavior in animals has been explained by kin selection and reciprocal action. ${ }^{11}$ A group of organisms that includes self-sacrificing individuals has a higher chance of survival than a group that doesn't. Altruistic behavior results when two principles are at work. It happens when the individual is, first, more likely to help close kin rather than distant ones, and, second, when that individual helps another with the expectation of having the favor returned. Ruse argues that, for some organisms, these conditions are indeed satisfied. Moreover, humans are such animals. Therefore their altruistic behavior is fully explainable in this naturalistic way.

What are the hidden logical nuances of this argument? In line with the sociobiology program sketched above, Ruse is essentially explaining, in purely naturalistic terms, one of the fundamental moral traits of human behavior. The suggestion is that what we can do as regards altruism may be done also as regards other moral habits. So the outcome of such an explanatory project seems to be inevitable: we are heading towards global determinism as regards human culture, because every human act would be seen as the outcome of biological mechanisms. Ruse is aware of this, and he tries to avoid such a slippery slope by a simple claim. He insists that arguments like the one about altruism are only about constraints our evolutionary past has established - nothing else. So he writes: "The question is not whether every last act of Western man or woman is governed by kin selection or reciprocal altruism or some such thing. I am sure it is not." 12

It is interesting to note that, in the very same book, he himself renders such an excuse somewhat ineffective. At one point he tries to remain at the level of broad, general principles allegedly touching only some constraints. At other places, he 
presents his thesis as relevant for the entire spectrum including both meta-ethics and normative ethics. In meta-ethics, we try to explain why humans adopt the moral principles that they in fact adopt. For instance, as regards altruism, we assume that humans show this tendency, the habit of helping others via self-sacrifice, as a common characteristic. Notice therefore that those engaged in a meta-ethical inquiry are not concerned with questions dealing with specific applicability, such as: "Should I be altruistic in this specific case?" The basic form of the question they are interested in is: "Why do we have this habit, most of us, most of the time, when it seems, at face value, to go against the survival of the fittest?" Habit and principle here merge into each other. Ruse is right in claiming that sociobiology is relevant here. As regards normative ethics, the relevance is less obvious. In normative ethics, the major focus is on the action to be done, not on the habits of the agent. The typical question here is of the form: "Should I do action $\underline{A}$ in this specific situation?" or "What am I obliged to do in this specific situation?" At first sight, it may appear that evolutionary explanation cannot be a useful resource for normative ethics, especially if we accept that an "ought" cannot be derived from an "is". We may however make evolutionary explanation relevant by inserting an ethical bridge-principle. And this is precisely what evolutionary ethics sometimes purports to do. It introduces the idea that: "we ought to do what is in line with our normal biological functioning". The plausibility of such an ethical bridge-principle makes Ruse's suggestion that sociobiology is relevant for both meta-ethics and normative ethics quite appealing. His caution as regards sliding towards global determinism doesn't stop him from supplying impressive arguments in support of Social Darwinism in its strongest form.

In spite of the attraction of extending evolutionary explanation beyond biology, there have been various arguments advanced against sociobiology. ${ }^{13}$ I will 
concentrate on one major issue only, one which has been somewhat neglected. I will focus on the very nature of intentional states. My basic claim is that the application of evolutionary explanation to moral, social and political philosophy tends to work with a view of intentional states that is to some extent distorted. Because of this, it ends up leaving some essential properties of human society out of consideration.

In what follows, the crucial assumption is that, although our main focus is Social Darwinism, it is often useful to start from more basic considerations. ${ }^{14}$ Take the human sciences in general. On close inspection, one realizes that a serious challenge arises because of the special character of mental states. Naturalists confront this challenge by adopting the methods of empirical science. For natural scientists, laws of nature in general are relations between some variables, and these variables are chosen in a specific way. The variables must, first of all of course, be useful in describing the phenomenon under study. They must also, however, be independent of each other. They must be both logically independent, in the sense that their meaning is accessible independently, and also methodologically independent, in the sense that they should be measurable separately. When this basic strategy is applied to ethics and social science, naturalists assume the existence of laws that express links between desires, beliefs and actions, and maybe some other elements of our normal way of behavior. So here we have the set of variables for this kind of inquiry. A typical law would be: for any human individual $\underline{\mathrm{x}}$, if $\underline{\mathrm{x}}$ desires $\underline{\mathrm{q}}$, and $\underline{\mathrm{x}}$ believes that doing action $\underline{\mathrm{A}}$ is the best means of attaining $\underline{\mathrm{q}}$, then $\underline{\mathrm{x}}$ does $\underline{\mathrm{A}}$. This is practically saying that the relations between intentional states and actions are assumed to be explainable on the model of causation in physics.

Is this viable? The major problem lies with one of the underlying assumptions. When we assume that what works for science must work also for ethics and society, 
we are assuming that intentional states are independent variables, while in fact they are not. They are, in fact, logically inter-dependent because of their intentional content. To determine the content of a belief or a desire, you need to ask the person who has them what he or she really believes or desires. Likewise, to determine an action, observing the bodily movement is not enough. This fundamental point rules out physics as a model for social and ethical explanation. Does it rule out biology as well? Admittedly, biology differs from physics in various ways. Evolutionary biology, for instance, is interested not in the relation between variables associated with a particular individual agent, but in what happens to average values of traits within a group. ${ }^{15}$ Could it be that, because of this shift in viewpoint from individual to group, the problematic mutual dependence between specific beliefs, desires and actions vanishes as we zoom out, as it were, from the scenario involving the individual? If it does vanish, or become negligible, then evolutionary explanation will indeed be applicable to social and ethical issues.

Only some further analysis, however, is needed to show that no such vanishing occurs. The problematic mutual dependence between beliefs, desires and actions resurfaces at all levels. At the level of the individual, this dependence is clear, as mentioned above. At the level of the group, mutual dependence between belief, desire and action takes the form of reflexivity. This term is used by critical theorists who are sensitive to the fact that knowledge and truth are dependent on human interests. For my purposes here, we can take the term reflexivity to refer to the fact that, in the human sciences, the objects under study (human beings) are not left undisturbed by the theories proposed to describe them. In concrete terms, this means that when a group is told about a theory proposed to explain its behavior patterns, the group is not only capable of shifting its behavior away from what is predicted, but very often does 
precisely that. The history of humanity gives ample evidence of this kind of reaction. And this shows how beliefs, desires and actions remain intertwined at the group level as well. The upshot is that evolutionary explanation of social and ethical behavior needs some fundamental revision even to get off the ground. ${ }^{16}$

Could it be that Social Darwinism is still defensible in spite of this problem? The only way forward is to claim that Social Darwinism is good for some aspects, but not for all aspects of moral and social behavior. Philip Kitcher seems to defend this middle-ground position. It is a position that corresponds very well, I think, to most people's pre-philosophical intuitions. His main point is that Darwinism, as an explanatory tool, has to be used with caution. When people appeal to natural selection in order to draw conclusions about psychological faculties and moral or social dispositions, their argument is always vulnerable. It is always open to the challenge that alternative explanations in these areas are possible. At best, a Darwinian explanation supplies us with an explanation not of how human morality and human social dispositions evolved but of how they might have evolved. To conclude his paper, Kitcher writes:

Darwin's great achievement doesn't make all other considerations and disciplines irrelevant, and, in particular, it shouldn't lead us to dismiss the potential insights of pre-Darwinian philosophizing. My recommendations for applying evolutionary ideas within philosophy are, I trust, obvious from my illustrative examples, and their prevailing character is one of cautious exploration. Darwin deserves his due, neither more nor less. ${ }^{17}$

In the terminology used above, Kitcher seems to be assuming, deep down, that intentionality can be divided into two layers. The lower layer corresponds to instinctive behavior; the upper level to non-instinctive behavior, where action is the 
result of conscious deliberation. For instinctive behavior, beliefs, desires and actions are so simple that they are indeed independent variables. A Skinner-type stimulusresponse scenario involves a person with a simple desire-belief-action sequence, such as when someone acts "mechanically", as we often say. Are there real desires, beliefs, and actions in these scenarios? Many of us would say yes. They are genuine desires, beliefs and actions, but they are not the object of our attention. They are not the object of attention either because the individual is alienated with something else, or because the individual is being carried along by the crowd. When, as it were, I don't look straight at my desires, beliefs or actions, I live in the mechanical mode. At any moment, however, I can stop and attend to them. When I do so, these intentional states become the object of my self-reflection. Up to now, I've been discussing the individual. But the argument applies also to a group. A group, or even the species taken as a whole, has beliefs, desires and is engaged in action. It is fully conscious of some of these beliefs, desires and actions. It may however be unaware of others. Hence, just as in the individual's case, the group can stop and attend to itself, in a moment of group self-reflection. In this way, its hitherto mechanical beliefs, desires and actions start becoming interdependent. It is therefore by attending to them, that the individual or group will detach itself from the picture supplied by the Darwinist account of social and ethical reality. Here we have the second layer of intentionality.

Kitcher's position seems balanced and plausible. Nevertheless, if I'm right about this hidden assumption involving two levels, it starts showing worrying signs of over-simplification. The idea of a clear boundary between intentional states in the mechanical mode and intentional states in the non-mechanical, or free, mode looks too good to be true. I fear that the world is messier than we often wish it to be. If, in our understanding of mental properties and of practical reason, we follow the route of 
Aristotle, as reworked recently by D. Davidson and J. McDowell, we'll see that there cannot be any clear distinction between empirical content and conceptual scheme. This essentially means that what I have been calling mechanical beliefs, desires or actions aren't beliefs, desires or actions at all. Once humans become aware of anything - once they become aware of cognitive dispositions, of basic wants or urges, or of possible control over bodily movement - their rationality is engaged, whether they like it or not. A mechanical action, after all, is, in so far as it is deprived of intention, not ethical. So what is the major issue in this entire debate? Even this very quick glance at mental properties and practical reason is enough to show that the major issue is human freedom. If Social Darwinism explains anything about humans, it explains what lies outside free deliberation. It explains what lies outside the specifically human.

Let me recapitulate: the aim of this section was to determine one of the root problems that is blocking further progress. I've structured my reasoning by listing some arguments in favor of Social Darwinism and some against. Concentrating only on intentional states, I've come to the conclusion that, when we apply evolutionary explanation to moral, social and political philosophy, we tend to ignore the basic fact that the content of human beliefs, desires and action are inter-dependent. We tend to disregard the human ability to react against constraints. The root problem is the stubborn fact of human freedom with respect to natural constraints.

\section{SOCIAL DARWINISM: THE RELIGIOUS PERSPECTIVE}

We shift now to the religious viewpoint. The interaction of Social Darwinism with Christianity has taken many forms. A quick historical glance shows that clashes 
occurred principally around the following four areas. ${ }^{18}$ First, Christianity defends the idea of human nature or human essence, and considers this indispensable as a basis for freedom. Social Darwinists, on the contrary, work with the assumption that there is no such thing as a fixed human nature or essence. This clash was first explicitly pointed out as early as 1866 in the first French translation of Darwin's Origin of Species. ${ }^{19}$ One needs to add here, however, that, since those early years, ideas on this point have evolved. Within the Darwinian camp, defenders of punctuated equilibrium have highlighted the fact that, although speciation is possible, species usually remain unchanged over long stretches of time; moreover, speciation occurs only within relatively brief intervals. Within the phylum that includes humans, significant biological changes haven't occurred for thousands of years. It is plausible to consider this point a satisfactory justification for the idea that, although human nature or human essence may not be fixed, it is virtually timeless. The second area of dissonance occurred because Christianity considers universal brotherhood as possible, and in fact never ceases to encourage people to strive to achieve it. Social Darwinists, on the contrary, insisted that human divisions are perennial because they are founded on tribal conflict. Humans in fact can never escape their dual mentality of being locally friendly, but globally belligerent. ${ }^{20}$ Thirdly, Christianity considers herself the channel of God's revelation to humanity, and, especially within the Catholic tradition, sees religion and science as necessarily harmonious with each other as they issue from the same source, God. On the contrary, influential, popular, Social Darwinists like Ernst Haeckel (1834-1919) argued that science and religion are in direct and eternal conflict and that what is valid in Christianity was taken from other cultures and what is specific to it is wrong. ${ }^{21}$ Fourthly, Christian tradition, especially within Catholicism and the Orthodox traditions, sees a vital spiritual value in priestly celibacy and in the 
idea of belonging to a community of shared norms. Social Darwinists opposed this. They argued that priestly celibacy is an encumbrance to society because it reduces the best offspring, and that conformity and tolerance blocks the purity of the superior race. $^{22}$

In spite of these areas of contention, the interaction of Social Darwinism with Christianity has enjoyed elements of constructive dialogue. For many centuries before Darwin's days, the Catholic intellectual tradition had been engaged in social and political philosophy in various ways. In spite of such a sustained effort, no complete, systematic theory of society has ever been formulated and officially sanctioned, even to this day. One sees rather a general attempt at highlighting a number of principles that must be respected at all costs. Social Darwinism has represented an opportunity for Catholic scholars to explore areas that had hitherto been neglected or simply ignored. I will proceed by examining three of these principles.

The first one deals with realism as regards the nature of all created things, including societies. Drawing from Aristotle and Augustine, official Catholic doctrine has always highlighted the idea of the autonomy of each aspect of reality: "created things and societies themselves enjoy their own laws and values which must be gradually deciphered, put to use, and regulated by men." ${ }^{23}$ The basic tenet of faith that God is the creator of everything justifies the assumption that all processes unfold according to their own laws. This holds not only for physical reality but for biological and social reality as well. To avoid sliding towards the idea that the goodness of the Creator ensures an easy access to these laws, the acknowledgment of this realism needs to be counterbalanced. It is counterbalanced by recalling the enormous complexity of reality: not only of physical reality, but also of biological and especially human reality. Any trace of reductionism in social explanation should therefore be 
viewed with suspicion. A typical statement highlighting this caution is found in an official text that expresses concern about the straightforward application of Marxist doctrines to society: "In the human and social sciences it is well to be aware above all of the plurality of methods and viewpoints, each of which reveals only one aspect of reality which is so complex that it defies simple and univocal explanation." 24 This caution is valid not only for Marxist explanation. It is valid also for Social Darwinism, for both explanations are practically always taken to be exhaustive.

This point leads naturally to the second principle highlighted within the Catholic tradition as regards social reality: the danger of having social theory hijacked by dangerous ideology. The usual victim of such hijacking is human freedom. That the application of Darwinism to social explanation is easy prey for ideology has been highlighted not only by religion-inspired scholars but also by others. ${ }^{25}$ The possibility of distortion arises because, in explaining a given social aspect, one can often choose the variables deliberately to support a hidden agenda. ${ }^{26}$ Social Darwinism has often been used in this way to support various forms of determinism that undermine moral responsibility.

Now, one needs to recall that the Catholic tradition does not say that human deliberation and choice are not determined in any way. The Augustinian and Thomistic heritage grapples with the question of freedom in relation to God's foreknowledge and God's omnipotence. Aquinas had no problem with proposing that the human will is, in its very nature, strictly determined toward an object recognized intellectually as the universal good. For him, human freedom is only possible when humans deal with particular goods. ${ }^{27}$ In such cases, deliberation and choice are indeed affected by the physical state of the individual. For instance, a person may be more emotional than another, or more impulsive than another, according to each person's 
temperament and prior conditioning. There may also be unconscious influences. Individuals are often not fully aware of all that is affecting their deliberation and choice. Nevertheless, it is legitimate in such cases to consider them free in the sense that they are deliberating and choosing consciously, while having the added commitment to uncover as many as possible of the hidden influences. When Social Darwinists therefore argue that moral choices are conditioned by habits hammered into human living in the course of hominid evolution, they are not out of line with the Catholic tradition. When they claim however that, because of such habits, moral choices are illusory, they are seen as contravening the basic principle of human freedom.

Not to remain too much on the abstract level, we may consider the particular example of economics and laissez-faire, or unrestricted, capitalism. As mentioned above, H. Spencer's writings on Social Darwinism had proposed that an economic system should allow businesses to operate with little or no government interference. With such an outlook, the role of society's deliberation and choice is reduced to a minimum. There is no trace of the fact that human beings are the sort of creature that, once a previously hidden influence on the run of things becomes visible, they become capable of deliberating about it. In the late nineteenth and early twentieth century, this kid of deliberation actually erupted in the United States, when state and federal governments came under pressure to regulate unrestricted capitalism via legislation on working conditions, wages, and child labor. ${ }^{28}$ In a recent official document, which offers a synthesis of much work from the Catholic tradition, one finds an explicit reference to this tension between, on the one hand, social forces that may be accounted for in terms of Darwinian principles and, on the other hand, human freedom and responsibility: 
The free market cannot be judged apart from the ends that it seeks to accomplish and from the values that it transmits on a societal level. Indeed, the market cannot find in itself the principles for its legitimization; it belongs to the consciences of individuals and to public responsibility to establish a just relationship between means and ends. The individual profit of an economic enterprise, although legitimate, must never become the sole objective. Together with this objective there is another, equally fundamental but of a higher order:

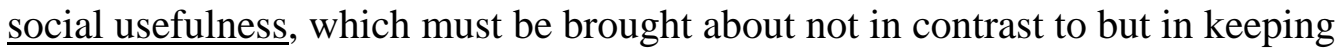
with the logic of the market. When the free market carries out the important functions mentioned above it becomes a service to the common good and to integral human development. $^{29}$

The suggestion here is that the laissez-faire mentality is not wrong in itself but is to be judged according to its service to the common good. The element of freedom and responsibility remains: a good illustration of the second principle I wanted to highlight, a principle that emerges in a new light because of the interaction between Social Darwinism and Catholic thought.

The third principle concerns the dignity of the human person. For an explicit formulation of this principle, in relation to evolutionary explanation, one may refer to a section of Pope John Paul II's address to the Pontifical Academy of Sciences delivered in 1996: "Theories of evolution which, in accordance with the philosophies inspiring them, consider the spirit as emerging from the forces of living matter or as a mere epiphenomenon of this matter, are incompatible with the truth about man. Nor are they able to ground the dignity of the person." ${ }^{30}$ The suggestion here is that, to be acceptable, any philosophy of evolutionary biology, and also any associated social theory, must consign to the human person absolute value. The theory must be able to 
ground the dignity of the person. This requirement is being presented as a constraint on the various possible uses of evolutionary explanation in understanding human reality. Hence, giving less importance to the individual person than to the genes that partially constitute him or her is unacceptable. Giving less importance to the individual person than to the aggregate (species or society), to which that person belongs is likewise unacceptable. The person comes first. No person is to be considered merely an instrument for the survival of the species. No person is to be considered merely a carrier of an exotic gene.

On this particular point, the fiercest ideological battles were fought in debates concerning Eugenics. The advent of Darwinism encouraged the consideration of the human phenomenon from new perspectives. It encouraged the study of traits, over and above the consideration of human individuals. It encouraged the study of populations, again over and above the consideration of individuals. The systematic study of methods for hereditary improvement of human population by controlled selective breeding arose concurrently with Darwin's work. In spite of this however, eugenics is quite distinct from Social Darwinism. Eugenics represents a kind of "reverseengineered" version of Social Darwinism. Darwin had started from the model of goaldirected animal-husbandry, and then moved on to the elimination of purpose. In eugenics we find the opposite. Francis Galton uses Darwin's views on natural selection to return to goal-directed human intervention: hence the popular idea that eugenics is the self-direction of human evolution. Having said that, however, we need to recall that the aim behind eugenics is very often in line with Social Darwinism. The idea of a struggle for survival is always in the background. What we often see within the eugenics movement is an acknowledgement that the struggle for survival of one 
particular race needs to be carried out intelligently and methodically. The upshot is: eugenics and Social Darwinism are strange bedfellows.

There is a lot to say about the complex reaction of the Catholic Church to the eugenic movement, especially to the forms that movement adopted in Nazi Germany. ${ }^{31}$ I will concentrate on one foundational point only, a point that illustrates the principle of the irreplaceable value of the individual person. This one foundational point is that, although there is much to condemn in the philosophy of eugenics, there are some elements that are in harmony with genuine human flourishing. Only if we highlight the value of the individual person, can we determine these positive elements in line with human flourishing. No one can deny that there is a moral obligation for one generation to ensure that the next generation enjoys a quality of life better than its own, or a quality of life at least as good as its own. For a correct judgment on how this can be achieved, one must respect the right priorities that determine the individual's deliberations. Hence, physical well-being cannot be taken to override moral and spiritual well-being. Such ideas were expressed by Catholic scholars not only in learned works but also in pamphlets directed to the masses. For instance, Thomas Gerrard in 1912 published a booklet entitled The Church and Eugenics. He explains how "instinct shall be ministrant to intelligence, and intelligence ministrant to love". ${ }^{32}$ In the same vein he writes: "the physical element in man must always be subordinate to the psychic and the psychic to the spiritual". ${ }^{33}$ His point is not that we should disregard or hinder the lower aspects. It is rather to care for them, but to do so in so far as they enhance the development of the higher aspects. The main question then emerges therefore is: what is the ideal that humans should seek? Gerrard argues that genuine Catholic doctrine brings out the best in eugenics. The Catholic "ideal" is neither Nietzsche's Über-Mensch, nor the humanists' Ideal Scientist or Ideal Artist. It 
is rather the genius in morality and holiness, or, in other words, the saint. $\mathrm{He}$ concludes: "Catholicism then, far from seeking to hinder eugenic reform, seeks rather to promote it by setting it on a lasting basis, the basis of the spirit". ${ }^{34}$ Gerrard's arguments are a good illustration of the Catholic trend to defend the dignity of the individual. The individual's freedom and responsibility explains why no one is to be considered merely an instrument for the survival or purification of the race.

\section{CONCLUSION}

In part one, I concentrated on purely philosophical issues, especially those dealing with intentional states. I arrived at the conclusion that one of the major problems concerns human freedom with respect to natural constraints, whether these constraints arise from immediate physical limitations or from more long-term conditioning. In part two, I explored some aspects of the way Social Darwinism interacted with Christian thought, especially in the Catholic tradition. In this regard, the religious viewpoint has highlighted three principles: realism as regards social reality; the danger of having social theory hijacked by dangerous ideology; and the absolute value of the person. These two parts of this chapter represent two distinct lines of inquiry, one deriving its inspiration from reason and observation; the other from reason, observation and religious faith. It is interesting to see how both lines of inquiry converge onto the same area. They both indicate that there is something wrong when Social Darwinism or sociobiology is allowed to stifle human freedom and responsibility.

The basic insight therefore that emerges from the foregoing arguments is that even if Social Darwinism or sociobiology supply convincing evidence that social 
injustice, war, or interpersonal aggression are natural, we are still obliged to exercise our freedom with respect to these aspects of human living and to do so responsibly. ${ }^{35}$ Social Darwinism and sociobiology do not hinder the role of social policy, still less do they eliminate it. On the contrary, they are a help. They tell us where we really stand. They facilitate effective planning. Admittedly, it often happens that, when beliefdesire-action sequences are left unattended, both at the level of the individual and at the level of society, they tend to become instinctive, ingrained, or mechanical: a kind of second nature. When this happens, any unwanted consequences may surprise us. This element of surprise should trigger our concern. Darwinism therefore is indispensable, not because our freedom is illusory but because we need all the information we can get so as to exercise freedom responsibly. 


\section{NOTES FOR CHAPTER TEN}

1 Herbert Spencer, Social Statics (London: Routledge/Thoemmes Press, 1996). 414-5. As regards biology, Spencer was in line with Lamarck rather than with Darwin. So for Spencer, new species emerged as a result of modifications in existing species, brought about by exposure to new conditions. They did not emerge via natural selection. See his essay "Progress: its Law and Cause," in: H. Spencer, Essays: Scientific, Political and Speculative (London: Williams \& Norgate, 1890).

2 Recent work in this area shows that Darwin's reasoning is incorrect on this point. A group-selection mechanism like the one he had in mind will die out in the long run because of infiltration into that group of selfish individuals. The egoism of these individuals will be advantageous within the group, and will thus undermine its moral standards. See: A. Rosenberg, "The Biological Justification of Ethics: a best-case scenario", Social Philosophy and Policy 8 (1990): 86-101; reprinted in: A. Rosenberg, Darwinism in Philosophy, Social Science and Policy (Cambridge: Cambridge University Press, 2000), 118-136.

3 In line with this volume's overall line of inquiry, I will concentrate on the Catholic religious viewpoint, without negating that a study of other religious viewpoints is of course important as well.

4 Mike Hawkins, Social Darwinism in European and American thought, 18601945: nature as model and nature as threat (Cambridge: Cambridge University Press, 1997), 31. For a detailed treatment of how Darwin's theory depends on its historical context, see: G. Radick, "Independence, history and natural selection" in: J. Hodge \& G. Radick, The Cambridge Companion to Darwin (Cambridge: Cambridge University Press, 2003), 143-67. 
5 Through the past decades, Darwinian explanation has been extrapolated beyond its normal habitat not only in the directions indicated here but also in other directions as well. Lack of space forbids considering these other areas at any length in this chapter. They include, for instance, (1) the relatively new area of teleosemantics, where works like R. Millikan, Language, thought, and other biological Categories: new foundations for realism (Cambridge, Mass.: MIT Press, 1984) and D. Papineau, Reality and representation (Oxford: Basil Blackwell, 1987) try to develop an evolutionary explanation of meaning and intentionality; (2) the area of phylogenetic relationship. This second area involves the search for a "family tree". A great deal of work in evolutionary biology is devoted to determining what the family trees are for various taxonomic groups. The detailed working out of ancestry is a separate task from the identification of the adaptive significance, if any, of the traits that various species possess. To see how elements of culture, or how existing languages, or how various manuscripts (like the four Gospels), are sometimes related to each other genealogically is a question in which insights from evolutionary biology can play an important role.

6 See Robert M. Young, "Darwinism is Social," in: David Konn (ed.), The Darwinian Heritage (Princeton: Princeton University Press, 1985), 609-38; the quote is from 623.

$7 \quad$ Principia Ethica (1903), chapter 2.

8 Two fundamental recent studies showing how a specific genetic constitution can determine, to some extent at least, what humans do are: W.D. Hamilton's original 1964 paper "The Genetic Evolution of Social Behaviour”, in: R. Axelrod, The Evolution of Cooperation (Ann Arbor, MI: University of 
Michigan Press, 1984); E.O. Wilson, Sociobiology: the New Synthesis

(Cambridge Massachusetts: Harvard University Press, 1975).

9 See also: Richard Nelson, "Universal Darwinism and evolutionary social science," Biology and Philosophy, 22 (2007): 73-94; Howard L. Kaye, The social meaning of modern biology: from Social Darwinism to sociobiology (New Haven (CT); London: Yale University Press, 1986).

10 It must be recalled that at present biologists are apparently divided on the question whether evolutionary biology justifies or negates functional explanation. Sociobiology shows the same split. Some conclude that the biological model illustrates how purpose and function is irrelevant within a society. Others conclude that the biological model illustrates the opposite.

11 Taking Darwin Seriously: a naturalistic approach to philosophy (Oxford, New York: Basil Blackwell, 1986; reprint with updates Prometheus Books, 1998).

12 Ibid., 230.

13 The major ones are: T. Nagel, "Ethics as an autonomous subject," in: G. Stent (ed.), Morality as a biological phenomenon (Berkeley: University of California Press, 1980), 196-205., where sociobiology is deemed useless because moral philosophy is an autonomous discipline; O. Flanagan, "Is morality epiphenomenal?" Philosophical Forum, 2/3 (1981): 207-25, where moral beliefs are shown to be too complex for sociobiology to handle; P. Kitcher, Vaulting Ambition: Sociobiology and the Quest for Human Nature (Cambridge, Mass: MIT Press, 1985), where sociobiology is accused of taking humans for fundamentally selfish organisms; A. Flew, "E.O. Wilson after Twenty Years: Is Human Sociobiology possible?" Philosophy of the Social Sciences 24/3 (1994): 320-35, where sociobiology is shown to entail genetic determinism that is 
incompatible with human freedom. For a reaction to these, see J. Lemos, “A defence of Darwinian accounts of morality," Philosophy of the Social Sciences 31/3 (2001): 361-85.

14 For more details, see L. Caruana, "A neglected difficulty with Social Darwinism," Heythrop Journal XLIX (2008), 652-58.

15 For more on how biology differs from physics, see: Alex Rosenberg, "Limits to biological knowledge" in his Darwinism in Philosophy, Social Science and Economics (Cambridge: Cambridge University Press, 2000), chapter 3.

16 For a general and responsible attempt at incorporating beliefs, desires and action within social explanation, see: Jon Elster, Explaining Social Behavior (Cambridge: Cambridge University Press, 2007). Because of the interdependence I talk about, he calls such variables fragile.

17 Philip Kitcher, “Giving Darwin his due," in: J. Hodge and G. Radick (eds.), The Cambridge Companion to Darwin (Cambridge University Press, 2003), 399420.

18 I'm drawing here from Hawkins, Social Darwinism in European and American thought.

19 It was expressed by Clémence-Auguste Royer in her "Avant Propos" to the second edition of her translation of Darwin's De l'origine des espèces (Paris: Guillaumin, 1866), and was then followed by a fuller, philosophical treatment by John Dewey, The Influence of Darwinism on Philosophy and Other Essays (New York: Henry Holt and Company, 1910).

20 For an example of this mentality, see Arthur Keith, Essays in Human Evolution (London Scientific Book Club, 1944). 


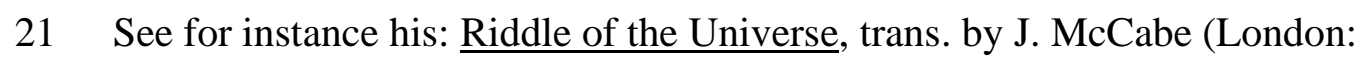
Watts \& Co., 1902).

22 For an early expression of this, see Georges Vacher de Lapouges (1854-1936), L'Aryen: son rôle social (Paris, 1899).

23 Vatican Council II, Gaudium et Spes, $§ 36$.

24 Congregation for the Doctrine of the Faith (1984), Instruction on certain aspects of the "Theology of Liberation", §5. See http://www.newadvent.org/library/docs_df84lt.htm

25 For instance S. Rose, L.J. Kamin, and R.C. Lewontin, Not in Our Genes: biology, ideology and human nature (Harmondsworth: Penguin, 1984).

26 The issue here is quite distinct from the influence of values in the development of science. See Robert C. Richardson, "Biology and ideology: the interpenetration of science and values," Philosophy of Science, 51 (1984): 396420.

27 See for instance Summa Theologiae I-II, Q.10, a.2: "if the will be offered an object which is good universally and from every point of view, the will tends to it of necessity, if it wills anything at all; since it cannot will the opposite. If, on the other hand, the will is offered an object that is not good from every point of view, it will not tend to it of necessity." See: The Summa Theologica of St. Thomas Aquinas, trans. The Fathers of the English Dominican Province (Online Edition by Kevin Knight, 2008) http://www.newadvent.org/summa/

28 A significant early opponent of economic liberalism from within the Catholic tradition was Heinrich Pesch, S.J., who was based mainly in Köln and died in 1926. His major contribution is found in his five-volume Manual on the 
National Economy (published 1905-1923), in which he attempted to integrate economic theory with Aristotelian-Thomistic categories of thought. He is considered by many the link between the papal encyclical Rerum Novarum (1891) and the corresponding encyclical Quadrogesimo Anno (1931).

29 Pontifical Council for Justice and Peace, Compendium of the Social Doctrine of the Church, (USCCB Publishing, 2005), $\$ 348$ (italics in the original).

30 Truth Cannot Contradict Truth: Address of Pope John Paul II to the Pontifical Academy of Sciences (October 22, 1996)_(English version in: L'Osservatore

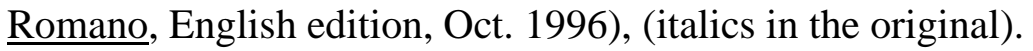

31 A crucial figure in Germany was Joseph Mayer, a Catholic priest, scholar of Eugenics and Moral Theology, and assistant in the Institut für Caritaswissenschaften at Freiburg. He wanted to establish a society on the model of Francis Galton's Eugenics Society in England. See: Ingrid Richter, $\underline{\text { Katholizismus und Eugenik in der Weimar Republik und im Dritten }}$ Reich: zwischen Sittlichkeitsreform und Rassenhygiene (Paderborn: F. Schöningh, 2001); Michael Burleigh, Death and Deliverance: "Euthanasia" in Germany 1900-1945 (Cambridge: Cambridge University Press 1994).

32 Thomas J. Gerrard, The Church and Eugenics (England-Catholic Social Guild, Catholic Studies in Social Reform No. 4, 1912; 2nd ed. 1917), 20.

33 Ibid., 23.

34 Ibid., 57; see also: Richard John Neuhaus (ed.), Guaranteeing the good life: medicine and the return of eugenics (Grand Rapids: Eerdmans, 1990).

35 A. Rosenberg makes this point against Kitcher in: "Grievous Faults in Vaulting Ambitions?" Ethics 98 (1988): 827-37. 